\title{
Diplopoda from Papuan Caves (Zoological Results of the British Speleological Expedition to Papua-New Guinea, 1975, 4)
}

\author{
by
}

\author{
Richard L. HOFFMAN*
}

The material of cavernicolous Diplopoda obtained by the British Speleological Expedition to Papua New Guinea in 1975 contains eight species representing eight genera and three families in the order Polydesmida. As might be expected from the remote location of the collecting sites, all of the species appear to be undescribed, as well as five of the genera. Of particular biogeographic interest is the inclusion of two species of the family Doratodesmidae, previously unknown east of Java.

Inasmuch as all species of Polydesmida are primarily eyeless, and since the legs and antennae are commonly much elongated in the family Paradoxosomatidae, it is difficult to assert that any of the species from the Papuan caves are actually troglobitic, although such a status seems likely for at least one in which the pigmentation appears to be considerably reduced.

A difficulty afflicting the present material is one shared with many other cave collections all over the world, namely that the cave fauna is far better known that the adjacent epigaean, making intelligible comparisons extremely difficult. Nonetheless the material at hand is of great interest in advancing the knowledge of the diplopod fauna of the central mountain ranges of New Guinea, and I express here my best thanks to Mr. Chapman and Dr. Beron for making it available for study. Primary types and most of the other specimens have been returned to the Bulgarian National Museum of Natural History; a few duplicate specimens are retained for my personal collection.

The majority of cave millipeds were taken from sites on the Finim Tel Plateau, located in extreme northwestern Papua, about $35 \mathrm{~km}$ west-southwest of Telefomin. Maps and other details are provided in a recent summary of the British New Guinea Speleological Expedition (Brook et al., 1976).

* Radford College, Radford, Virginia 24142, USA. 
Order Polydesmida Leach, 1814

Family Paradoxosomatidae Daday, 1889

Paradoxosomatidae Daday, 1889, Termesz. Füzetek, vol. 12, p. 133.

Strongylosomatidae Cook, 1896, Proc. U. S. Nat. Mus., vol. 18, p. 82. Strongylosominae Attems, 1898, Denkschr. Akad. Wien, vol. 67, p. 271. Hylomidae Cook \& Loomis, 1924, Washington Acad. Sci., vol. 14, p. 104. Strongylosomidae Attems, 1937, Das Tierreich, lief. 68, p. 24.

Paradoxosomatidae Jeekel, 1963, Stud. Fauna Surinam, vol. 4, p. 8; 1968, Classification and Geographical Distribution of the Family Paradoxosomatidae, pp. 5-162.

The taxonomy of this large and heretofore much-confused family has been brought to a state of comprehensibility by the work of Jeekel during the past several decades, culminating in his masterly synthesis in 1968. From this reference it is clear that the paradoxosomatid fauna of New Guinea is dominated by the members of two tribes in particular: Eustrongylosomatini and Aschistodesmini. A third tribe, Tectoporini, occurs in New Guinea only as represented by a species of Heliocorthomorpha which may have been introduced.

\section{Eustrongylosomatini}

Eustrongylosomatini Jeekel, 1968, Paradoxosomatidae, p. 35.

Diagnosis: "Paradoxosomatidae in which the femur of the first pair of legs of the male is not modified. Acropodite of gonopods with a femorite lacking a chitinous demarcation between femur and postfemur, but sometimes with lamellate expansions, and usually produced somewhat distally from the base of the tibiotarsus. Tibiotarsus elongate, consisting only of a solenophore sheathing the solenomerite. The lamina lateralis basally produced into a rounded lobe." (Jeekel, op. cit.)

Components: Eustrongylosoma Silvestri, 1898; Perittotresis Attems, 1914; Nothrosoma Attems, 1929; Astromontosoma gen., n.; Selminosoma gen. n.

Distribution: New Guinea; New Ireland; Solomon Islands; Mindanao.

Key to genera of Eustrongylosomatini:

1. Metazona produced laterally into prominent acute paranota . . Nothrosoma

- Metazona with paranota represented, if at all, only by low swellings or low

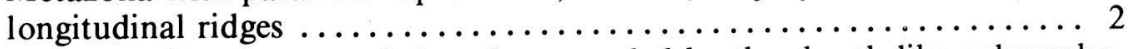

2. Solenomerite of gonopods largely concealed by the sheath-like solenophorous modification of the tibiotarsus $\ldots \ldots \ldots \ldots \ldots \ldots \ldots \ldots \ldots$

- Solenomerite not enveloped by the tibiotarsus, mostly visible as seen in

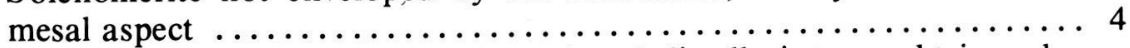

3. Postfemoral region of gonopod produced distally into a subtriangular or acute process near base of tibiotarsus; metazona with relatively distinct 
transverse sulcus, lacking a series of median pores .... Eustrongylosoma

- Postfemoral region of gonopod not produced or lobed adjacent to base of tibiotarsus; metazona lacking transverse sulci, but segments 5-18 with a small median pore in a depression in the sulcal position .... Perittotresis

4. Tibiotarsus of gonopod abruptly and obviously reflexed proximad adjacent to base of solenomerite, distal end prominently expanded and laminate; course of prostatic groove concealed by a femoral lamina originating on ventrolateral side of the groove ................. Selminosoma

- Tibiotarsus of gonopod continuing direction of postfemoral region, no proximad reflexure, but apical end attenuated and slender; prostatic groove visible for most of its length in mesal aspect, but subtended in part by a median femoral lamina located on dorsal side of the groove .............

Astromontosoma

\section{Eustrongylosoma}

Eustrongylosoma Silvestri, 1896, Ann. Mus. civ. stor. nat. Genova, vol. 36, p. 198. Type species, Strongylosoma fasciatum Silvestri, 1895, by original designation and monotypy.

Thalatthipurus Attems, 1932, Res. sci. Voy. Indes Or. Neerl., vol. 3, no. 12, p. 10. Type species, $T$. castaneus Attems, by original designation.

Mimosoma Chamberlin, 1920, Bull. Mus. Comp. Zool., vol. 64, p. 125. Type species, M. glabrum Chamberlin, by original designation.

?Papuosoma Chamberlin, 1945, Amer. Mus. Nov., no. 1282, p. 11. Type species, $P$. cladis $C$ hamberlin, by original designation.

Eustrongylosoma: Jeekel, 1967, Tijdschr. Ent., vol. 110, p. 344 [synopsis].

Present knowledge of this genus derives almost entirely from the recent studies of Jeekel, appearing in his papers of 1967 and 1973. Since the type species fasciatum was very inadequately documented by Silvestri, Eustrongylosoma fell into the category of genera incertae sedis where it languished for seventy years, during which time several other names were proposed out of indifference or inadvertance for species closely related to fasciatum. But the way is now clear for constructive work on this large group of organisms which dominate the paradoxosomatid fauna of the Papuan region and, in fact, the southwest Pacific region in general.

As defined in Jeekel's 1967 paper, Eustrongylosoma included a total of six species from New Guinea itself; later (1973) he added the five species from the Solomon Islands which Chamberlin had published under the generic name Mimosoma. Unstudied material in my possession shows the existence of a rich representation on the Caroline island Ponape, as well as the occurrence of the genus on Mindanao. Unquestionably Eustrongylosoma contains a large number of species from this enormous generic range, but as Jeekel has already observed there is considerable heterogeneity and perhaps the genus will be subdivided during the course of future studies. 
Although I have not personally restudied authentic material of any species of Papuosoma, the brief descriptions and vague drawings published by Chamberlin in 1945, as well as geographic considerations, make a very strong circumstantial case that this "genus" too is just another synonym for Eustrongyloso$\mathrm{ma}$. On the basis of this conviction, I venture to present below a highly provisional key to the known New Guinea species based on external characters. It obviously should be used in connection with published accounts and a strict cognizance of geographic localities, and in no way suggests actual relationships.

Among the millipeds taken in the Selminum tem cave system is a very small species referable to Eustrongylosoma as currently defined. There being no suggestions whatever of the usual cave modifications, occurrence of this animal in the cave is obviously accidental.

\section{Key to New Guinea species of Eustrongylosoma}

1. Apex of epiproct "bifid", that is, with two long, slender decurved acute

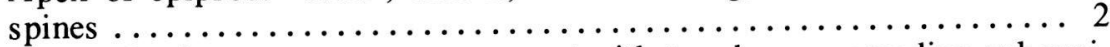

- Apex of epiproct truncate, or at most with two low paramedian subconi-

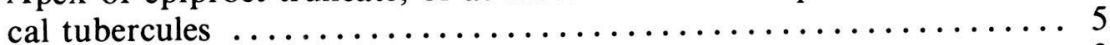

2. Metaterga of segments 5-17 with evident transverse sulcus $\ldots \ldots \ldots .3$

- Metaterga without transverse sulcus $\ldots \ldots \ldots \ldots \ldots$ bifasciatum

3. Dorsum with distinct light median band $\ldots \ldots \ldots \ldots \ldots$ fasciatum

- Dorsum without distinct longitudinal light band $\ldots \ldots \ldots \ldots \ldots \ldots 4$

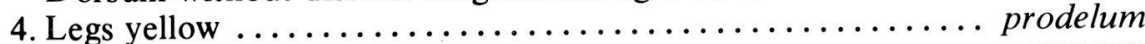

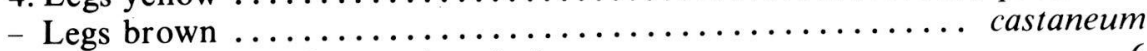

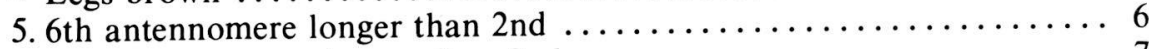

- 6th antennomere shorter than 2 nd ...................... 7

6. Metaterga without transverse sulcus; width less than $1.0 \mathrm{~mm}$. . exiguum

- Metaterga with evident sulcus; width greater than $1.5 \mathrm{~mm} \ldots \ldots \ldots .7$

7. Paranota greatly reduced, hardly more than ovoid swellings on sides ...

- Paranota of normal size for the genus $\ldots \ldots \ldots \ldots \ldots \ldots \ldots \ldots$

8. Dorsum uniformly light brown ................ obesum

- Dorsum with at least suggestion of color patterns ............ 9

9. Each metatergum with inverted $\mathrm{Y}$-shaped yellow mark ....... cladis

- Tergal pattern not as described above .................. 10

10. Metaterga with two pairs of oblique light stripes $\ldots \ldots \ldots \ldots$ versicolor

- Tergal pattern not as described above .................. 11

11. Dorsum with a sharply-defined continuous yellow stripe .... typonotum

- Dorsum with only traces of a pale narrow median stripe ... oenologum 
Eustrongylosoma exiguum, sp. nov.

(Figures 1-6)

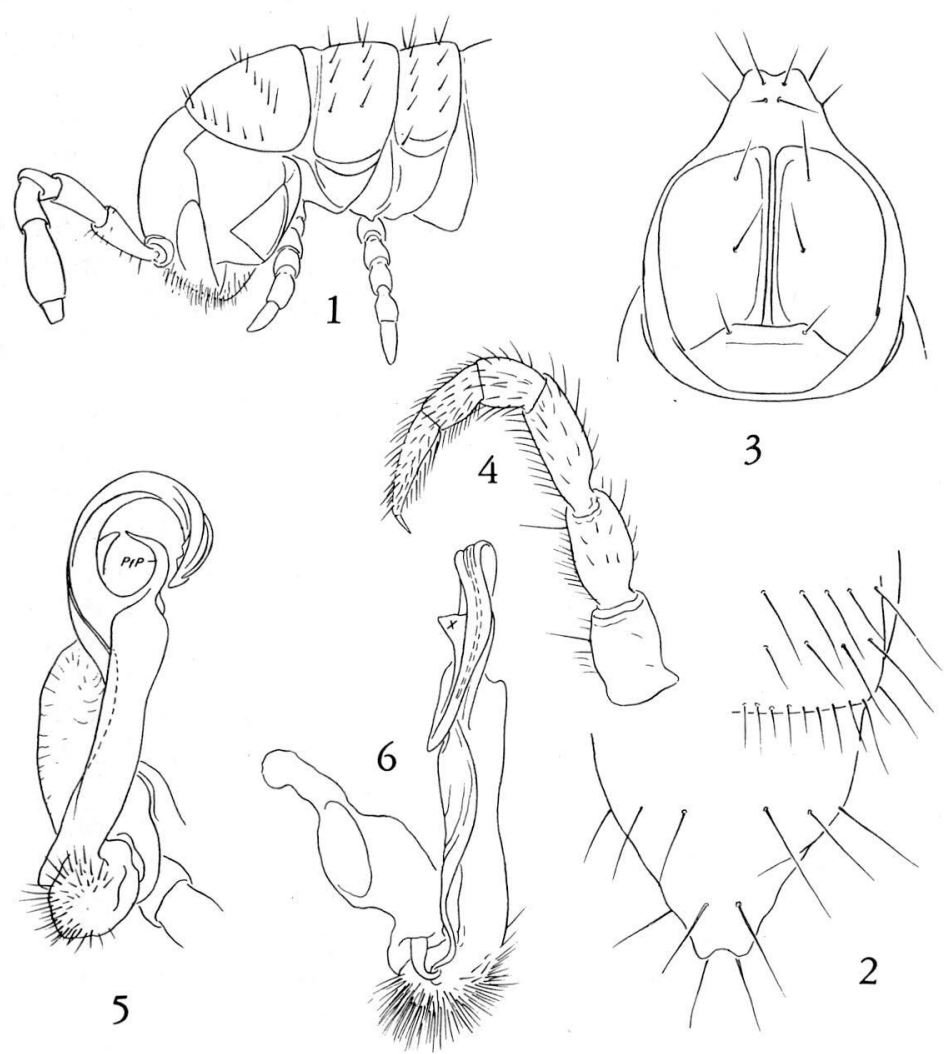

Material. - New Guinea: Papua, Western Province, Finim tel Plateau: Selminum Tem Cave. Adult male, 18 November 1975 (B.S.E. Collection No. ST-6).

Diagnosis. - A very small member of the genus (length $12 \mathrm{~mm}$ ); with median dorsal light band; transverse metatergal sulcus visible only on anteriormost segments, otherwise absent; segments beyond midbody with three transverse series of long setae; tip of epiproct subtruncate; tarsi with numerous long setae but no true subtarsal brush developed on any legs.

Holotype. - Broken into three pieces, length about $12 \mathrm{~mm}$, maximum width, $0.9 \mathrm{~mm}, \mathrm{~L} / \mathrm{W}$ ratio ca. $7.5 \%$. Body generally parallel-sided back to about segment 18, except segments 3 and 4 are slightly smaller in diameter and thus create an anterior constriction.

Coloration after one year in spirit: metaterga dorsally light brown, entire collum and a broad sharply-defined median dorsal band ivory white; sides of 
segments, paraprocts, sterna, and coxae clear testaceous. Postfemora, tibiae, and tarsi, and ventral sides of femora and prefemora, brown, except first pair of legs which are entirely white. Top of head dark brown, face, mandibles, and 1 st antennomere testaceous, 2 nd-5th antennomeres light brown, 6th and basal half of 7 th dark brown, distal half of 7 th white.

Head convex in the antennal region, flattened below, epicranial suture distinct but not depressed; genae weakly convex, not margined laterally. Antennae set below middle of head, isthmus slightly greater than length of 1st antennomere. Two pairs of paramedian epicranial setae, one pair of interantennal setae; other facial setae obscured by intermixture with numerous irregular hairs. Antennae relatively short, extending back only to middle of 3rd segment, articles 2-5 similar in size and shape, article 6 thicker and about 50\% longer than others, with prominent oval sensory pit on outer end; 7 th small, cylindrical, truncate, with four tiny cones. All articles except 1 st about equally setose.

Collum about as broad as head across mandibles, surface smooth and polished, lateral ends broadly rounded, anterior edge finely margined up to level of mandibular base; an anterior series of 5-5 long setae adjacent to front edge of collum and a similar series of 5-5 across the median region.

Body segments with metazona distinctly larger in diameter than prozona, the two separated by a deep prominent stricture, its surface costulated but without sharp edges. Texture of both subsegments uniformly smooth, with microscopically fine isodiametric meshes. Segments 3 and 4 smaller than 2 and 5 , and with traces of transverse metatergal sulci, these obsolete on 5th and not evident on subsequent segments. Anterior to midbody region, metaterga with two transverse series of setae as on collum, the row originally in a median location gradually migrates to the caudal margin, and around the 10th segment a third row appears in the median position. Paranota virtually obliterated, only a slightly indication of a peritreme indicated by a short, arcuate groove just below the pore opening. Pores large and conspicuous, in the usual sequence.

Epiproct of the form shown in Fig. 2, the paramedian tubercules short and inconspicuous. Paraprocts and hypoproct as illustrated in Fig. 3.

Sterna without modifications, moderate in width, sparsely setose, medially depressed. Legs (Fig. 4) relatively short and stout, with numerous long setae, denser and longer on ventral side of tarsi, but no true tarsal brushes developed. Relative length values of podomeres as follows: $3=6>2>1>5=4$.

Stigmata strikingly dissimilar in size and shape, anterior stigmata subpyriform, distinctly elevated above and set off from surface of metazona, extending well into stricture, about three times as large as posterior stigmata which are suboval, only moderately elevated. Both pairs of stigmata located above and slightly in front of dorsal coxal condyle.

Anterior legs unmodified, vasa deferentia opening in a median position directly onto surface of 2 nd coxae, no trace of tubercule or process evident. No indication of femoral gland in 1 st or 2 nd legs. Sternum of segment 5 with conspicuous, spatulate, median process between anterior legs, its sides parallel, the end rounded and distinctly curved cephalad, anterior side prominently setose. Sternum of segment 6 broadened and medially depressed. 
Gonopods as shown in Figs. 5 and 6. Coxae (including sternal apodeme) shorter than telopodite, strongly constricted at midlength, with a few short setae on lateral side. Telopodite elongate, nearly straight, with a large flange on dorsal side of femur, dorsad to course of prostatic groove. Tibiotarsal region forming a nearly complete circle curving laterad and completely enclosing solenomerite, with an accessory subbasal triangular lamina on dorsal side (Fig. $6, \mathrm{X}$ ); a long; slender, curved postfemoral process visible in ventral aspect (Fig. 5 , PFP).

\section{Astromontosoma, gen. nov.}

Type species. - A. jeekeli, sp. nov.

Diagnosis. - A genus of Eustrongylosomatini with well-developed paranota, ozopores opening in longitudinal grooves on lateral sides of peritremata and invisible from above; metaterga with transverse sulcus present back to 18th segment and four setae in a transverse series in front of the sulcus. Head without supra-antennal convexity; antennae long and slender, 5th and 6th articles abruptly clavate distally, 6th with with circular, sharp-edged sensory pit on outer side. Sternum of 6th segment of male with unusually high and narrow median process, other sterna unmodified. Legs of 1-10 pairs of male with tibiae distally swollen ventral at the distal end and invested with a dense field of long simple setae which extends halfway along ventral side of tarsi. Stigmata large, convex, elevated above surface of segment, anterior and posterior stigmata dissimilar in shape.

Gonopods with relatively small coxa and prefemur; acropodite greatly elongated, femoral region with both medial and dorsal flanges; prostatic groove mostly visible in mesal aspect; solenomerite not concealed by tibiotarsus, latter bent into a loose semicircle, not reflexed or cingulate at its base, forming a narrow blade without branches or other modification.

Etymology. - The generic name is a neologism referring to the occurrence of the type species in the Star Mountain range of western Papua, plus the conventional suffix "-soma" frequently used in generic names in this family.

Comments. - I can offer at this time no meaningful opinion on the affinities of this taxon. The type and only known species shows a mixture of generalized and specialized characters (in the latter category the modifications of the anterior legs and of the stigmata are especially noteworthy), and until the New Guinea fauna of Eustrongylosomatini becomes much better known (there are probably numerous genera to be disclosed, and hundreds of species), any ideas about relationships can only be speculative. In any event, Astromontosoma is not closely related to any of the presently-known genera. 
Astromontosoma jeekeli, sp. nov.

(Figures 7-14)

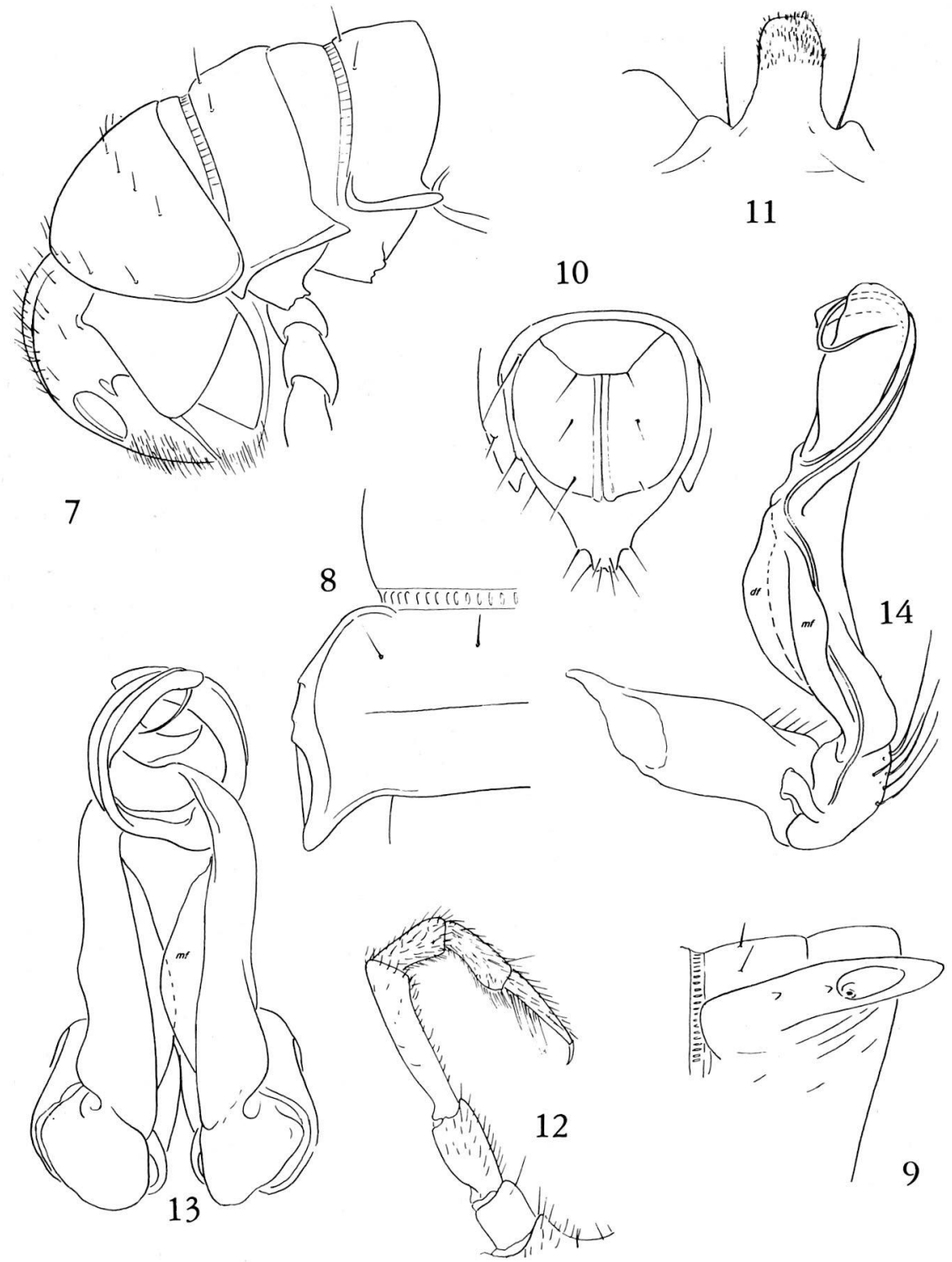

Material. - New Guinea: Papua, Western Province, Finim tel Plateau: Upper Bitip Cave, west chamber. Adult male, 11 November 1975 (B.S.E. Collection No. FT-11). 
Diagnosis. - With the characters of the genus.

Holotype. - Broken into several pieces, length about $23 \mathrm{~mm}$, maximum width, $2.4 \mathrm{~mm}, \mathrm{~L} / \mathrm{W}$ ratio ca. $11 \%$. Coloration after one year in spirit: head, mandibles, collum, antennae, and dorsum of segments light brown; upper sides of paranota, sides and venter of segments, legs, and apical antennomere white.

Head of normal configuration. Interantennal space relatively wide, almost twice length of 1 st antennomere; no supra-antennal convexity present. Epicranium with a pair of enlarged setae just above level of antennae and a similar pair about halfway back to edge of collum; lower half of face rather densely setose without setal pattern evident. Antennae long $(3.8 \mathrm{~mm})$ and slender, extending back to 5 th segment; antennomeres 2-4 similar in size and shape, 5 and 6 a little longer and each prominently expanded distally on the outer side, 6 with a prominent sensory organ, the field of sensory hairs withdrawn into a nearly circular, sharp-edged cavity; 7 th article about twice as long as broad, distinctly convex on its outer side. Four tiny apical sensory cones.

Collum slightly narrower than width of head across mandibles; almost uniformly oval in outline, surface smooth and polished, with 3-3 enlarged setae just behind anterior edge, and a somewhat smaller seta placed marginally at lateral end of collum (perhaps part of the same series); 3-3 setae in a transverse row just behind midlength of collum.

Trunk segments with well-developed paranota, set high on sides and nearly horizontal, giving appearance of the Orthomorpha body form. Paranota of segment 2 (Fig. 7) larger than the others, projecting forward under end of collum and there produced into a prominent outward and downward projecting acute lobe, posterior corner also acutely produced. Segments 3-18 generally similar in form (Figs. 8, 9), transverse sulcus of metazona well-defined, extending almost to peritremata; 2-2 macrosetae located just in front of sulcus, no other setae evident; prozona moderately telescoped, paranota not overlapping except on posteriormost segments. Stricture shallow but well-defined, prominently costulate. Pore formula normal; pores opening at anterior end of a distinct lateral depression of the peritreme and not visible in dorsal aspect, ventral surface of peritremata concave below and behind level of pore, lower edge of the depression thus distinctly carinate. Lateral edge of paranota normally with three fairly distinct denticulations.

Last segment of normal shape (Fig. 10), subconical, surface smooth, dorsally with four basal and distal macrosetae, apex abruptly smaller and slightly decurved apical setal whorl, the four terminal setae visible in ventral aspect; paraprocts without particulars, hypoproct bluntly truncate, without median projection and without distinct setiferous tubercules.

Sterna glabrous, about as wide as length of prefemur, produced into small knobs at base of coxae, otherwise unmodified. Legs and slender, coxae and prefemora somewhat incrassate, the more distal podomeres distinctly thinner, sparsely setose except for tibiae and tarsi; tarsal claw long, nearly straight; length ratio: $3>6>5>2>4>1$. Legs of segments $2-8$ (=1st-10th pairs) of the form shown in Figure 12, tibiae swollen distally on the ventral side and there densely setose, similar setation extending along basal half of tarsi. 
Sides of segments smooth and unmodified except for poorly defined pleurosternal "ridges" visible back as far as 8 th or 9 th segment. Stigmata large and prominent, elevated above level of segment and microgranular in texture, the anterior subpyriform, the posterior nearly circular in outline.

Sternum of 5 th segment with a high, narrow, distally truncate median process (Fig. 11) between anterior pair of legs. Other anterior sterna unmodified. $G$ onopod aperture without raised rim, only the anterior margin projecting slightly medially. Gonopods extending over sternum of 6th segment, of the form shown in Figs. 13 and 14. Coxae relatively small and short, with a few setae on the dorsolateral surface, sternal apodeme short. Prefemur small, subovoid in shape, densely setose, separated from remainder of telopodite by a distinct constriction. Femoral region elongate, with a large laminate median flange $(\mathrm{mf})$ located dorsal to course of prostatic groove, and a dorsal flange ( $\mathrm{df}$ ) facing the coxa. Solenomerite arising from median side of telopodite, not enveloped by tibiotarsus, the prostatic groove visible for most of its length. No postfemoral region set off. Tibiotarsal blade curved through a half circle and slightly twisted near its base, neither cingulate nor reflexed at base.

Etymology. - This interesting species is named in honor of my friend, and outstanding diplopodologist, C. A. W. Jeekel.

Selminosoma, gen. nov.

Type species. - S. chapmani, sp. nov.

Diagnosis. - A eustrongylosomatine genus in which (in the type species) the body is extremely long and slender ( $\mathrm{L} / \mathrm{W}$ ratio 7-9\%), apparently colorless, legs and antennae long and slender (more than twice maximum body diameter). Paranota reduced to low ridges, set off by grooves only at distal third of length, ozopores located at extreme posterior end of paranota. Metaterga with transverse sulcus on segments 5-19; anterior segments with two transverse series of about 4-4 setae, beyond midbody a third row of about 8-8 setae appears on posterior edge of metaterga. Head of normal configuration, two pairs of epicranial setae, lower part of face densely invested with setae of variable length. A pex of epiproct with two acute projecting paramedian tubercules. Podosterna divided into anterior and posterior halves by unusually deep transverse groove between coxae. Legs long and slender, unmodified in males, wothout ventral brushes or hairpads. Stigmata large, prominent, projecting outward as finely granular rounded cones, the anterior slightly the larger, both set in a distinct rounded rim. Sternum of 5 th segment with a small median triangular lobe betwee anterior pair of legs. Other sterna unmodified.

Gonopods with relatively small coxa and prefemur; femoral region with ventromedian flange which conceals course of prostatic groove; no demarcation between regions of the acropodite; tibiotarsal region strongly reflexed proximad at its base; solenomerite exposed for its entire length; apex of tibiotarsus curved laterad, ending in two prominent lobes of the lamina medialis; lamina lateralis small. 
Etymology. - The generic name is a neologism derived from the Selminum Tem cave system and the conventional suffix "-osoma."

Selminosoma chapmani, sp. nov.

(Figures 15-22)

Material. - New Guinea: Papua, Western Province: Finim tel Plateau, cave Selminum Tem, ô holotype, 3 ô and 3 q paratypes, 15 November 1975; numerous $\delta$ and $q$ paratypes, 18 November 1975 ; $1 \delta$ and $1 \%$ paratypes, 19 November 1975 .

Diagnosis. - With the characters of the genus.

Holotype. - Adult male, length ca. $22.5 \mathrm{~mm}$, maximum body diameter, $1.5 \mathrm{~mm}, \mathrm{~L} / \mathrm{W}$ ratio, ca. $7 \%$. Body appearing extremely slender and moniliform, of nearly equal width except at segments 2-4 which are slightly narrower than 5-18.

Coloration almost uniformly very pale testaceous, legs and antennae white, entire animal probably pure white when alive.

Head without special modification; epicranial suture weakly defined, antennae set just below middle of head and separated by a space about equal to diameter of a socket; face nearly flat, genae not notably convex and not margined laterally. Two pairs of paramedian epicranial setae and the interantennal pair apparently displaced dorsad almost to level of lower epicranials; remainder of facial setae not detectable because of profuse setation.

Antennae long (ca. $3.5 \mathrm{~mm}$ ) and slender, extending back nearly to base of 5 th body segment; articles 2-6 virtually identical in size and shape, each very slightly clavate distally, 6th a little shorter and thicker than the others, with prominent suboval sensory pit on outer end; 7 th cylindrical and much longer than usual, nearly half the length of 6 th, with four minute sensory cones. All articles destad to 1 st with abundant long erect slender setae.

Collum without particulars, transverse, the posterior edge nearly straight, lateral ends broadly rounded, anterior edge generally subarcuate, without evident margination. Surface smooth and polished, with a row of 4-4 setae near anterior edge, and about 4-4 across midlength.

Second segment with relatively conspicuous paranota, continuing slope of dorsum and thus directed virtually straight ventrad, subtending ends of collum. Subsequent segments long with reference to width and only very slightly telescoped, prozona and metazona of nearly equal diamter, separated by a broad, shallow constriction (Fig. 15), surface of prozona with microscopic isodiametric mesh, surface of metazona smooth and polished; stricture fairly wide and differing from adjoining surfaces in texture, being densely smooth and polished, ivory-like, with a transverse series of fairly large punctures. Metaterga of segments 5-19 with vaguely defined transverse sulcus, with two transverse series of about 4-4 setae back to midbody, whence a third row of shorter and more numerous (ca. 8-8) appears along caudal edge of segment. Paranota small and poorly defined except as posteriormost third where set off above and below by 


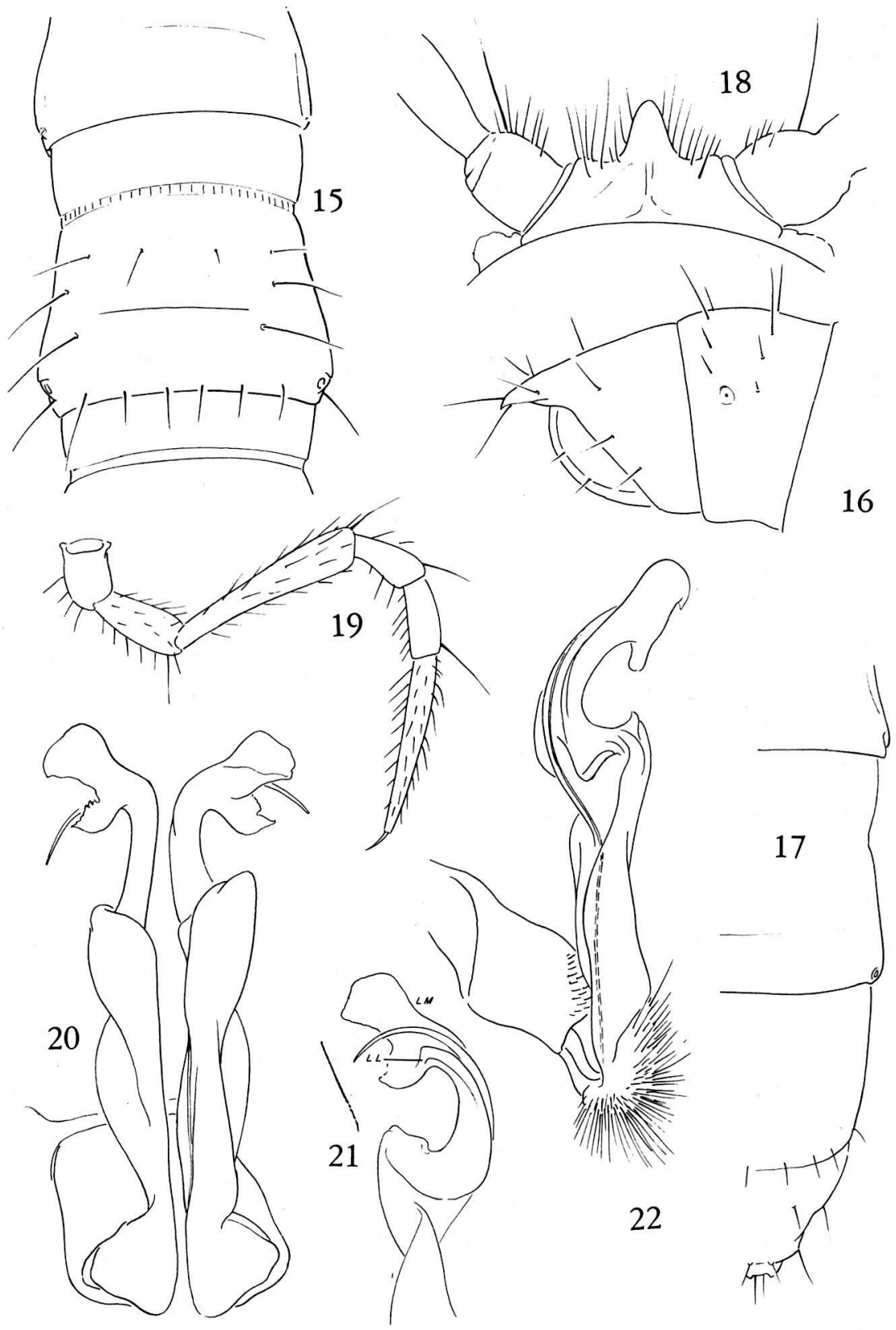


grooves, ozopores located at extreme posterior end of paranota where subtended by a prominent seta (Fig. 15). On segment 19 , paranota are essentially absent, and pores open directly from lateral surface of metazona (Fig. 17).

Epiproct relatively broad basally, becoming truncate apically, projecting well beyond paraprocts (Fig. 17), with slightly decurved spiniform paramedian terminal tubercules, the four apical setae arising between them. Paraprocts smooth and polished. Hypoproct large, flat, semicircular in outline, paramedian setae not set on tubercules, removed slightly in from edge.

Podosterna unusual, each completely divided by the transverse groove between the coxae which is deeper than the longitudinal median depression; sterna only about as wide as length of coxae, sparsely setose. Legs (Fig. 19) long and slender, but not becoming longer on posteriormost segments, $3 \mathrm{~d}$ and 6th podomeres the longest, about equal to each other and twice as long as 2 nd, 4 th, and 5 th; total length of midbody leg ca. $3.3 \mathrm{~mm}$, thus more than twice body diameter. Tarsal claw long, slender, nearly straight. Podomeres distad to coxa with numerous long erect setae, similar to those of antennae.

Sides of segments smooth and unmodified, pleurosternal carinae visible only on 2 nd and 3rd segments, relatively large and cristate on 2 nd, very poorly defined on 3rd. Stigmata large and conspicuous, each subhemispherical and set in a distinct circular rim, microgranular in texture and contrasting sharply with adjacent segmental surface; anterior somewhat the larger and located on dorsal coxal condyle, posterior smaller and placed slightly in front of condyle.

Anterior legs without modifications, tarsi with somewhat more profuse ventral setation, but no suggestion of subtarsal brush or pad developed on any legs. Sternum of segment 5 with a small triangular laminate median process between anterior legpair (Fig. 18), other sterna unmodified.

Gonopods (Figs. 20-22) of the general eustrongylosomatoid type, coxae of moderate length and with a field of small setae on dorsal side; base of telopodite with prominent flange originating on medial surface ventrad to course of prostatic groove which it largely conceals (Fig. 22), solenomerite mostly free and applied against surface of tibiotarsus, latter short, with two large apical lobes, curved laterad, strongly reflexed proximad at its base. A small acute postfemoral projection adjacent to the point of flexure. Distal lobes apparently modified from lamina medialis; lamina later " $"$ (if correctly identified) reduced to a small short flange visible on dorsal side (Fig. 21, LL).

Paratype. - Adult female, agreeing very closely in structure with male except in terms of body proportions as usual, length $20 \mathrm{~mm}$, maximum width $1.8 \mathrm{~mm}$, $\mathrm{L} / \mathrm{W}$ ratio $9 \%$.

Sterna somewhat wider than in male, broader than length of a coxa. Pleurosternal carinae evident on segment 4 as well as 3 .

Remarks. - I believe it is safe to assume that in this species we have a true troglobite. The uniformly decolorized body of all specimens, and greater development of long setae on legs and antennae suggest modification for cave life. Futhermore, this is the only species which was taken in large numbers in any of the Papuan caves, the others being found as individuals or very small series and thus probably trogloxenes. Obviously, a better knowledge of the adjacent epi- 
gaean milliped fauna of the central Papuan mountains will facilitate more accurate inferences of this sort.

In general, however, $S$. chapmani is notable for its want of any particularly specialized features such as were mentioned for Astromontosoma jeekeli.

Some notes on the biology of this species have recently been published by its collector (Chapman in Brook, 1976), indicating not only adaptation to cave life, but even more astonishing, a remarkable toleration of immersion in water. $\mathrm{Mr}$. Chapman's observations amply warrant quotation. In discussing the fauna of Selminum Tem, he writes (op. cit, p. 194):

"Further downstream is a small side passage with a damp but deeply cracked mud floor. Two remarkably interesting troglobites inhabit this side passage and the main flood-liable passage from which it leads. One is a long-legged, white and eyeless millipede; and the other is an eyeless harpaline carabid beetle.

"This millipede. . is by far the commonest and most ubiquitous troglobite in Selminum Tem. It is found only where the humidity approaches saturation, and usually close to water. The Bone Wells passage was visited only hours after a serious flood had passed through, and at this time millipedes could be seen emerging from cracks in the mud where they had taken refuge from the flood. Others had already emerged from their refuges and had moved onto the freshly deposited mud. The tolerance of the species to total immersion in water is remarkable. In another part of Selminum Tem, considerable numbers of millipedes of this, and a smaller species, were observed on the floor of a large, shallow pool, while other individuals of both species were walking on the surface film. The pool was fed by a small trickle, and had a dark brown floor which was in contrast to the surrounding pale, grey-brown silt of the cave floor. It is possible that micro-flora on the pool bottom were providing an energy-rich food source for the millipedes in an otherwise energy-poor environment."

To the best of my knowledge this is the first published record of any polydesmoid preferentially entering the water, although an unpublished observation made in central Tennessee, U.S.A., establishes the same behavior for Oxidus gracilis (K och), also a member of the family Paradoxosomatidae.

Possibly the somewhat divergent structure and texture of the stigmata, noted in the foregoing description, contribute to a hydrophobic condition preventing entry of water into the tracheal system.

\section{Nothrosoma}

Nothrosoma Attems, 1929, Rev. zool. bot. Afr., vol. 17, p. 277. Type species, Orthomorpha acuta Attems, 1914, by original designation and monotypy. Nothrosoma: Jeekel, 1967, Tijdsch. Ent., vol. 110, p. 366.

This name is adopted only as an expedient frame of reference for an unsatisfactory taxonomic situation.

There exist in the known Papuan fauna of paradoxosomatids two species in which the paranota are unusually well-developed and in their width and acuity strikingly resemble the condition common to Orthomorpha and some other 
genera of mainland Asia. Nonetheless on the basis of gonopod structure Jeekel perceived these species to belong to the Eustrongylosomatini.

The first of these animals to be made known was found at Hughibagu and Moroka, New Guinea, and described as Strongylosoma loriae by Silvestri in 1895 , although owing to the brevity of the description loriae was effectually a nomen dubium until 1967 when Jeekel redescribed the type material. In 1914 Attems published the name Orthomorpha acuta for material from Mosso, northern New Guinea, and in 1929 he set up the new monotypic genus Nothrosoma for this species. In his 1967 paper on the Silvestrian species, Jeekel referred $S$. loriae to Nothrosoma, pointing out the similarities with $N$. acutum in shape of the paranota and general form of the gonopods. The two are quite dissimilar in size, however, and in some characters of the male sex. Aside from those mentioned by Jeekel, I note that in acutum the solenomerite appears to be largely exposed, but enveloped by the tibiotarsus in loriae. Moreover, Attems says “. . . kurz, massig breit, hinten gerade abgestutzt" regarding the epiproct of acutum, whereas in loriae it is long and provided with two acute paramedian spines; and “. . . ungefähr trapezisch" for the hypoproct of acutum, which Jeekel's drawing shows to have two large paramedian tubercules in loriae.

It is clear, that if these species are indeed congeneric, they are at opposite ends of the generic structural spectrum.

The picture is complicated by females collected in the cave Kabim tem by Dr. Beron. On the basis of paranotal form, the species is referable to Nothroso$m a$, yet a number of departures in peripheral details would seem to imply generic distinction from at least $N$. loriae which is adequately described and figured. Yet, until males of the new species are known, and $N$. acutum has been restudied carefully, I hesitate to establish the new generic name that seems to be required. For the present, all three of the species mentioned are suborned under Nothrosoma. They may be readily distinguished by the following contrasts, exclusive of gonopodal differences.

Key to the species referred to Nothrosoma:

1. Epiproct short, apically truncate; hypoproct subtrapezoidal, without paramedian tubercules; body small, width less than $3.0 \mathrm{~mm} \ldots \ldots \ldots \ldots .2$

- Epiproct long, terminating in two prominent acute paramedian spines; hypoproct with two large spiniform paramedian projections, the edge between them concave; body larger, width $4 \mathrm{~mm}$ or more. loriae (Silvestri)

2. Body colorless (white); paranota of poriferous segments with a deep notch near midlength, ozopores located on ventral side at some distance from lateral edge; proximal setae of paraprocts set farther apart than distal pair ..

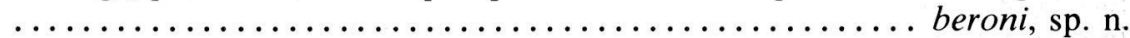

- Body dark brown, almost black dorsally; paranota of poriferous segments not prominently notched, pores located on paranotal edge ". . . nach aussen und ventral gerichtet. .." (characters of paraproctal setae unknown) .... $\ldots \ldots \ldots \ldots \ldots \ldots \ldots \ldots \ldots \ldots \ldots \ldots \ldots \ldots \ldots \ldots \ldots$ acutum (Attems) 
Nothrosoma beroni, sp. n.

(Figures 23-28)
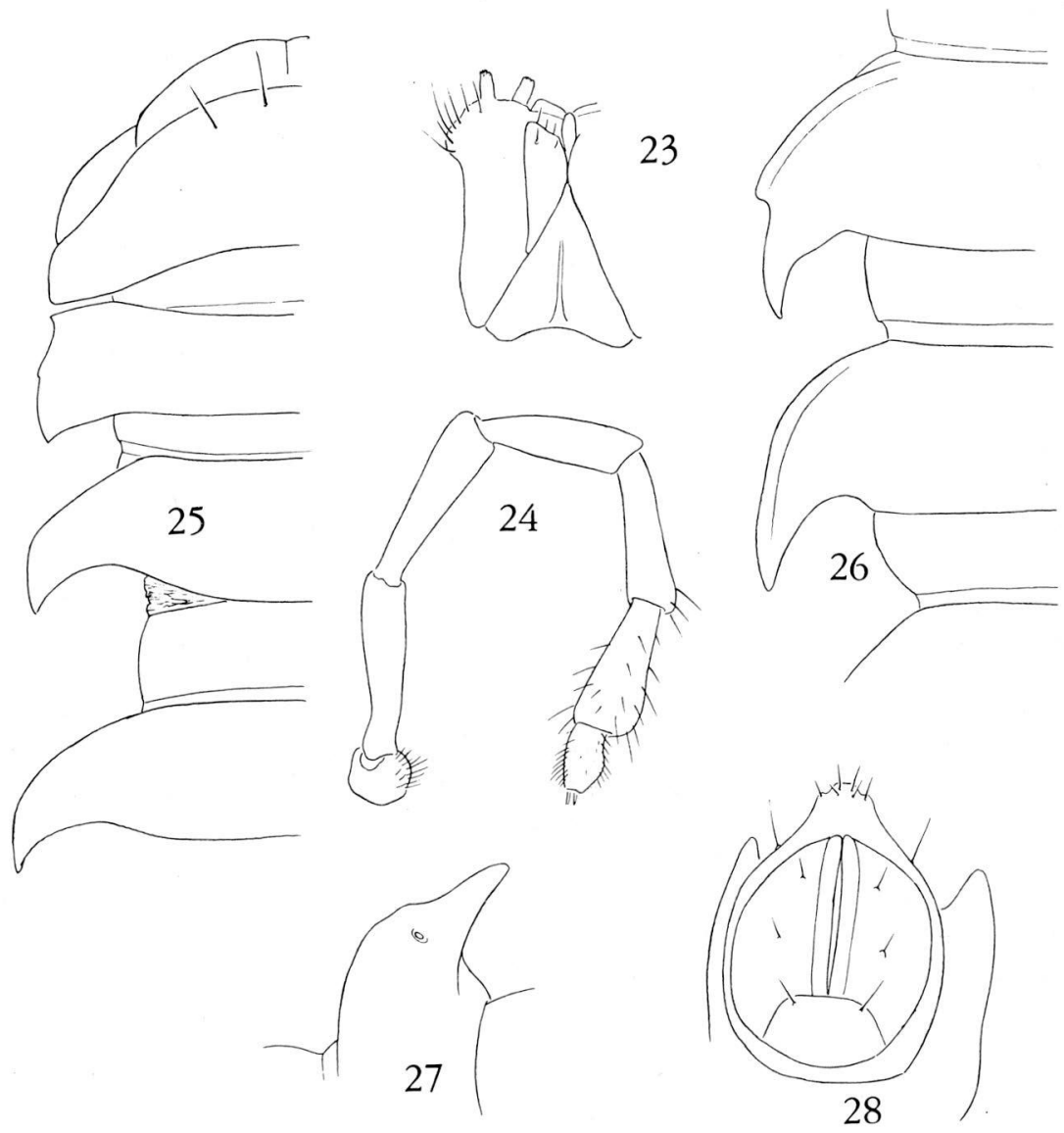

Material. - New Guinea: Papua, Western Province, Finim tel Plateau: cave Selminum Tem. Three adult females, 18 November 1975 (B.S.E. Collection No. ST-6).

Diagnosis. - Easily distinguished from the two known Papuan species having a similar habitus by the characters cited in the foregoing key: deep lateral paranotal notches, ventrally displaced ozopores, and wider placement of the proximal paraproctal setae.

Holotype. - Adult female, broken into three parts, approximate length $19.5 \mathrm{~mm}$, maximum width, $2.6 \mathrm{~mm}, \mathrm{~L} / \mathrm{W}$ ratio ca. $13 \%$. Coloration poorly developed, most segments pale testaceous, with edges of paranota, legs, and 
antennae white (it is uncertain if the specimen is only teneral or the reduced pigmentation is due to cave adaptation).

Head of normal configuration, less convex than in Eustrongylosoma, interantennal space about equal to diameter of a socket; genae not margined, edge forming a distinct offset over lateral end of labrum. Two paramedian pairs of epicranial setae, one pair of interantennals, other facial setae dense and irregular, but about 5-5 enlarged clypeal and 5-5 labral setae evident. Antennae (Fig. 24) long and slender, extending back to 5th segment, articles 2-5 general similar in size and shape, 6th shorter and thicker, 7th cylindrical, subfusiform, narrowed at base and apex, 6th with prominent rounded-oval sensory pit at outer end. Length values $3>2>4>5=6>7>1$. Gnathochilarium (Fig. 23) with prominent median carina on mentum; distal third of stipes lobed strongly laterad and setose.

Collum (Fig. 25) unusual in shape, lateral ends set off, interrupting slope of median region, nearly horizontal, with oblique lateral edges and acute posterior corner; surface of collum smooth and polished; four paramedian setae near anterior edge.

Body segments 5-17 generally similar in size and form, prozona and metazona about equal in size, separated by a large deep constriction, segments only slightly telescoped (only about one-third of prozona are concealed), the body thus appearing "loose jointed" with widely separated paranota. Latter large, elevated above the horizontal. Segments 5-18 with transverse metatergal sulcus, the surface smooth and polished, with 1-1 paramedian setae in front of the sulcus. Segments 2-4 slightly smaller and narrower than those following. Stricture with sharp-edged anterior margin, very feebly costulate.

Paranota of segment 2 (Fig. 25) with prominent deep notch in lateral margin, setting off anterior corner as acute lobe; segments 3 and 4 with slender, acute caudally-directed paranota. Paranota of poriferous segments with prominent indentation of lateral margin (Fig. 26), the ozopores displaced onto ventral surface about halfway from edge to base (Fig. 27), opening on posterior side of a slight convexity. Paranota increasingly produced on posterior segments, the apices blunt, slightly incurved; on segments 15 and 16 the produced region of paranota about equal to length of metaterga at median line.

Epiproct (Fig. 28) without special modification, subconical, the end truncate and slightly deflected ventral, the apical four setae thus directed ventrally, paramedian apical tubercules not enlarged. Paraprocts with raised mesal edges, the two proximal setae placed somewhat further from the median rim than the distal pair. Hypoproct large, smooth, flat, subtrapezoidal, paramedian setae not located on marginal tubercules.

Metazona with slightly elevated podosterna, sparsely setose, with broad median longitudinal depression and shorter, more pronounced transverse groove between coxae on each side. Legs long and slender, distal half of femora visible from above beyond level of paranotal edges. Relative lengths of podomeres: $3>6>2>4=5>1$; third about twice length of second, third and sixth almost of equal length, second subfusiform, third, fourth, and fifth apically a little clavate. Tarsal claw long and slender. 
Sides of metazona unmodified, no pleurosternal carinae evident on any segments. Stigmata similar in size, anterior a little more convex distad to its opening, posterior nearly flat, both raised above level of segment. Both stigmata located adjacent to dorsal coxal condyle, subpyriform in shape, with the narrow end directed anteriad and ventrad.

\section{Aschistodesmini}

Aschistodesmini Jeekel, 1968, Paradoxosomatidae, p. 33.

Diagnosis: "Paradoxosomatidae in which the femur of the first pair of legs of the male is provided with a ventral glandular process or tubercule. Gonopod coxa elongate, slender, in rest considerably protruding from the gonopod aperture. Acropodite of gonopods lacking chitinous demarcations between femur, postfemur and tibiotarsus. Solenomerite short, finely acuminate, neither sheathed nor applied to the tibiotarsus." (Jeekel, op. cit.)

Components: Aschistodesmus Pocock, 1898; Dendrogonopus Jeekel, 1964.

Distribution: Papuan region, from Halmahera to the Solomon Islands.

\section{Aschistodesmus}

Aschistodesmus Pocock, 1898, in Willey: Zool. Results. . \& \& c, pt. 1, p. 69. Type species, $A$. maculifer Pocock, by original designation and monotypy. Solomonosoma Chamberlin, 1920, Bull. Mus. Comp. Zool., vol. 64, p. 122. Type species, $S$. manni Chamberlin, by original designation.

Xenosoma Chamberlin, 1945, Amer. Mus. Nov., no. 1282, p. 15. Type species, $X$. atyches Chamberlin, by original designation.

Aschistodesmus: Jeekel, 1964, Nova Guinea, Zool., vol. 29, p. 107; 1968, Paradoxosomatidae, p. 34.

This rather distinctive genus is fairly widespread in the Papuan region, extending from Halmahera to the Solomons. In 1968, Dr. Jeekel referred 16 names to the group, without judgements on their validity although it seems likely that several of the species published by Chamberlin and Attems will be found to be junior synonyms. Six species appear to occur on New Guinea, certainly only a small fraction of the actual fauna of this genus. The British Speleological Expedition obtained a small series of females and immatures of an Aschistodesmus which is almost certainly undescribed, but ignorance of the male characters forbids the publication of a name for it.

\section{Aschistodesmus sp.}

Material. - New Guinea: Papua, Western Province; cave Ok Kabim Tem, near the village Assitubip, immatures, October 15, 1975; also cave Feram Tem, low passage at stream level, $2 \%$, without date.

The larger adult female measures about $30 \mathrm{~mm}$ in length and $3.8 \mathrm{~mm}$ in maxi- 
mum width, placing this species amongst the largest known in the genus. The metaterga are uniformly light chocolate brown with edges of the paranota whitish. Each metatergum has a transverse row of 2-2 setae just behind the stricture, and 3-3 adjacent to the posterior edge. The transverse sulcus is welldefined, as well as a median longitudinal suture.

Specimens with 18 segments or less have two distinct marginal denticles on the paranota, in those with 19 or 20 segments the lateral margins are completely smooth. Paranota of the adults are appreciably more produced caudally than as shown by Jeekel (1967) for $A$. albipes (Silvestri), and the epiproct is considerably narrower apically.

\section{Family Doratodesmidae Cook, 1896}

Doratodesmidae Cook, 1896, Brandtia, no. 2, p. 7.

Oniscodesmidae (in part) Attems, 1914, Arch. Naturgesch., vol. 80, Abt. A, no. 4, p. 179; 1940, Das Tierreich, lief. 70, p. 337.

Doratodesmidae Hoffman, 1977, Pacific Insects, vol. 17, p. 248; 1977, Rev. suisse Zool., vol. 84, p. 705.

The first known representative of this Asiatic-Indonesian family was described as Doratonotus armatus by Pocock in 1894. Two years later, O. F. Cook (1896: 7,27 ) proposed the new name Doratodesmus (Doratonotus being preoccupied), briefly described two new species, and set up the new family Doratodesmidae for this single genus, without a word of comment on its affinities with other polydesmoid groups. Sinclair (1902) added a new species to "Doratonotus" from caves in the Malay peninsula.

In 1914, Graf Attems placed Doratodesmus in the family Oniscodesmidae, a melange of small tropical millipeds having the ability to roll into a ball. Admittedly this was a measure of expediency, Attems noting that the gonopod structure was virtually unknown for most of the referred genera. Subsequently a variety of Asiatic genera were added to this family. In 1945 Chamberlin described the taxa Hoplitesmus and Pauroplus from Sumatra, Verhoeff (1939) Kylindogaster from Japan, Miyosi (1956) Eucondylodesmus from Japan, and finally Murakami (1966) Dimorphodesmus also from Japan.

Jeekel (1955) pointed out that Hoplitesmus is a synonym of Doratodesmus. The present author has dealt with this group in two papers appearing in 1977, the first containing the description of the new genus Ascetophacus from the Malay peninsula and some arguments for revival of Doratodesmidae as a valid family. The second added another species of Ascetophacus, and set up the new generic name Cetastelachys for Doratonotus cavernicola of Sinclair.

Up to the present time, then, the Doratodesmidae appears to be a family endemic to southeast Asia (Malaya to Japan, south to Sumatra and Java), generally closely related to the Polydesmidae and Cryptodesmidae as evidenced by the structure of the gonopod coxae and the sternal opening which contains them. The following genera have been established:

Doratodesmus Cook, 1896 (syn. Doratonotus Pocock, 1894, Hoplitesmus 
Chamberlin, 1945). Four or five species, Java and Sumatra.

Eutrichodesmus Silvestri, 1910. One species, Vietnam.

Pauroplus Chamberlin, 1945. One species, Sumatra.

Eucondylodesmus Miyosi, 1956. One species, Japan.

Dimorphodesmus Murakami, 1966. One species, Japan.

Ascetophacus Hoffman, 1977a. Two species, Malaya.

Cerastelachys Hoffman, 1977b. One species, Malaya.

It was accordingly of great interest to discover that the British Speleological Expedition obtained two additional genera of the group in the Finim Tel caves. This is really a large range extension, and brings the family eastward across Wallace's Line into a quite different zoogeographic region. The utter remoteness of the locality precludes any possibility of accidental introduction of the species from somewhere else, a possibility much more likely for the Japanese forms. Presumably additional doratodesmids can be expected from western New Guinea and the islands between it and Java, as the result of careful soil sampling.

Although quite a lot of structural diversity is manifested amongst the seven genera previously known, and the two new ones proposed herin, it is not feasible at the present time to essay their organization into tribes or subfamilies. Such an undertaking must be based largely upon a detailed study of the male genitalia, and in any event, would almost certainly prove to be highly premature if attempted at the present. It may be noted in passing that the largest species, and those having prominent middorsal segmental projections, are confined to Java, Sumatra, and Malaya. Species known from more peripheral localities are much smaller and devoid of dramatic ornamentation.

The two species taken in the Selminum Tem system are similar in body form and conservatively might be placed in the same genus. Consistency with the criteria applied in other diplopod groups, however, requires that the observed differences in at least gonopod structure be reflected by separate generic standing for the two species.

\section{Scolopopyge, gen. nov.}

Type species. - S. pholeter, sp. nov.

Diagnosis. - A genus of Doratodesmidae in which the adult male has only 18 segments. Epicranium broadly expanded laterally in front of mandibular bases, forming a conspicuous shallow antennal concavity. Genae strongly convex, tuberculate, with a broad flat lateral flange. Labrum and clypeus conjointly elevated, smooth and polished. Antennae separated by a distance about equal to half the length of 1 st antennomere. Metaterga with two transverse rows of 7-7 elongate rectangular or ovoid raised areas, the surface of which is finely and densely invested by minute sphaerical granules. No median dorsal processes formed. Pores on segments $5,7,9,10,12,13,15,16,17$, opening flat on surface of paranota near posterior end. Tip of epiproct bluntly truncate, the four apical setae subtended by a small but sharp and distinct median spine. 
Legs unmodified, tarsi however much more slender than other podomeres, coxae in contact medially. Coxae of 2 nd pair of legs of male produced distally into a slender conical setose process.

Gonopods large, coxae mostly exposed but firmly attached to edge of socket, set somewhat obliquely; telopodite reduced in size, oriented almost transverse to median body axis, prefemur massive, setose, without processes, acropodite consisting of a thin acuminate medially-directed solenomerite and a slightly larger laminate tibiotarsal blade; prostatic groove follows a course almost $360^{\circ}$ around lateral side of telopodite to gain entry onto ventral surface of solenomerite.

Etymology. - The generic name is a neologism composed of the Greek elements Scolopos (thorn) and -pygos (tail).

Scolopopyge pholeter, sp. nov.

(Figures 29-35)

Material. - New Guinea: Papua, Western Province: Finim Tel plateau, Bitip Cave, Upper West Chamberlin, $\delta$ holotype, $q$ paratype, 3 immature $q$ with 17 segments, 1 immature ô with 18 segments, 11 November 1975.

Diagnosis. - With the characters of the genus.

Holotype. - Adult male with 18 segments, originally tightly enrolled and necessarily broken into pieces for study, original length about $8.5 \mathrm{~mm}$, maximum width $1.6 \mathrm{~mm}$.

Coloration apparently affected by preservation, in general light to medium brown dorsally, the transverse tergal fields darker; antennae and legs white; sides of body, head, and terminal segment light brown to testaceous. Prozona with a large white median spot and a somewhat smaller light oval spot on each side and slightly behind the median, the three joined by a transverse light band in the stricture on some segments.

Head singular in form (Fig. 29), generally polydesmid in the ventral prolongation of the labrum, this and clypeus together elevated, smooth and polished, contrasting sharply with remainder of head which is densely granular overall; genae strongly convex medially and tuberculate, with a broad, flat, lateral lobe; antennal sockets set close, width of isthmus about half length of 1 st antennomere; epicranium broadened laterally and depressed behind antennae, forming together with lateral edge of genae and anterior flattened surface of mandible a prominent antennal concavity; a small but distinct lobe above each antennal socket, continued distolaterally as the dorsal edge of the antennal depression. Antennae short and massive, of the form shown in Fig. 29, 6th article with large oval sensory pit: four minute sensory cones on the cylindrical 7 th article.

Collum not as wide as head, transversely oval, the ends a little acuminate, entire perimeter ornamented with densely placed irregular tubercules and clusters of tubercules, a median depression with subovoid flattened area on each side, these spaces with small clusters of three to six small tubercules, tending to form short longitudinal ridges. 


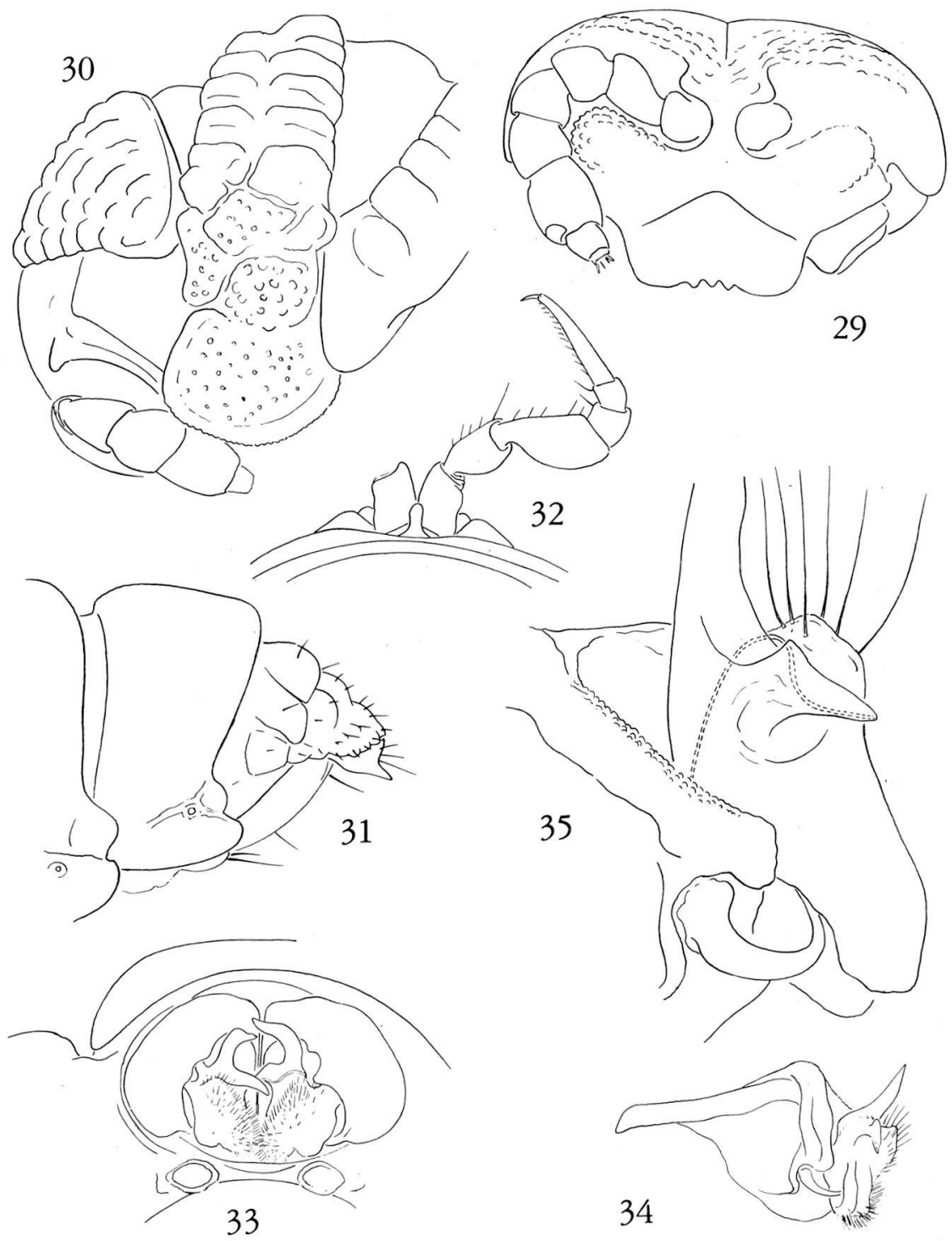

Second segment (Fig. 30) with paranota enlarged, flabellate, the ends broadly rounded, upper surface tuberculate, paranotal base with four irregular elevated areas subtending two transverse rows of 7-7 elongate rectangular congruent raised areas, these densely covered with minute sphaerogranulae.

Segments 3-17 generally similar in form, metazona greater in diameter than prozona, stricture broad and shallow, anterior edge sharp across midventrum, 
thence reduced to a faint line curving forward on prozona running dorsad nearly up midlength of that subsegment. Metaterga with usually 7-7 subrectangular or elongate-oval raised flattened areas in two transverse series, a single elongated area along base of paranota; latter small, directed nearly ventrad, anterior and posterior corners rounded, anterior projecting forward over stricture on most segments, posterior projecting caudally on segments 16 and 17; posterior edge of paranota with a subtriangular area. Raised areas generally smaller and irregularly arranged on segment 17 . Ozopores on segments 5, 7,9, $10,12,13,15,16$, and 17, large and conspicuous, located near the base of the subtriangular paranotal area.

Epiproct large, with three transverse series of raised areas (Fig. 31), about 3-3 in the basal row, 2-2 in the second, indistinct and irregular in the third; apex of epiproct blunt, short, considerably surpassing level of paraprocts, its ventral median edge prolonged into a short, straight, acute projection subtending the four apical setae. Paraprocts convex laterally but forming a flat surface at their mesal contact, proximal ends projecting basad over caudal edge of 17 th segment. Hypoproct large, trapezoidal, the end truncate, paramedian tubercules inconspicuous.

Sterna flat, continuous with inner ends of pleuroterga, latter lobed laterad to each coxal socket; legs set close together, the coxae in contact on all segments, with a small median sternal projection at the base forming the median condyle. Stigmata small, circular, flush with sternal surface, unmodified, placed slightly anterior to outer end of coxal sockets. Legs moderately long and slender, normally not visible beyond decurved ends of paranota but tarsi would be visible from above if extended laterad, podomeres of the form shown in Figure 32, tarsi notably long and slender. Anterior legs and sterna unmodified. Sternum of 2nd pair of legs fused to pleuroterga of 3rd segment, coxae of these legs produced distally into long conical, apically setose processes. Caudal edge of 3 rd segment produced into subtriangular lobe on each side of sternum.

Gonopod opening large, ovoid, inner rim of posterior edge expanded inward forming a transverse flange supporting distal ends of gonocoxae; latter large and massive, broadly in contact medially, set oblique in the aperture (Fig. 33). Telopodites relatively small and oriented almost transverse to median body axis, prefemora massive, in contact medially, densely setose. Acropodite region reduced to a slender acuminate, simple solenomerite blade and a similar, somewhat longer distally directed tibiotarsal remnant with a small triangular lobe on its lateral side at base. Prostatic groove (Fig. 35) curved almost $360^{\circ}$ laterad around base of acropodite, running out on ventral side of solenomerite.

Paratype. - Adult $q, 1.7 \mathrm{~mm}$ in width 19 segments. Body brownish, the anteriormost segments dark, shading to almost testaceous at the posterior end, without trace of median prozonal spots (perhaps decolored). Agreeing very closely with male in external characters. 
Selminarchus, gen. nov.

Type species. $-S$. hispidus, sp. n.

Diagnosis. - A genus of doratodesmid millipeds agreeing very closely in most external features with Scolopopyge, with the following points of difference noted: adults of both sexes with 18 segments (females of $S$. pholeter with 19); head not modified, epicranium not broadened laterally in front of mandibular bases and beyond ends of genae to form an antennal cavity; surface of body segments not microgranular, but invested with a dense covering of fine, short, microsetae; diameter of metazona only a little greater than that of prozona; areas of metaterga only slightly elevated, more irregular in arrangement with often three rows present; epiproct shorter, without ventromedian spine.

Gonopods similar to those of Scolopopyge in form of coxae, but telopodite simpler in form: prefemur merging gradually and imperceptably into a relatively short simple laminate acropodite, its end curved slightly ventromediad; prostatic groove without torsion, remaining on dorsal side of gonopod to tip of acropodite.

Etymology. - The name of this genus is a fanciful neologism composed of the collection site and the Greek noun "archos" (ruler), in reference to the size of the type species.

Selminarchus hispidus, sp. nov.

(Figures 36-38)
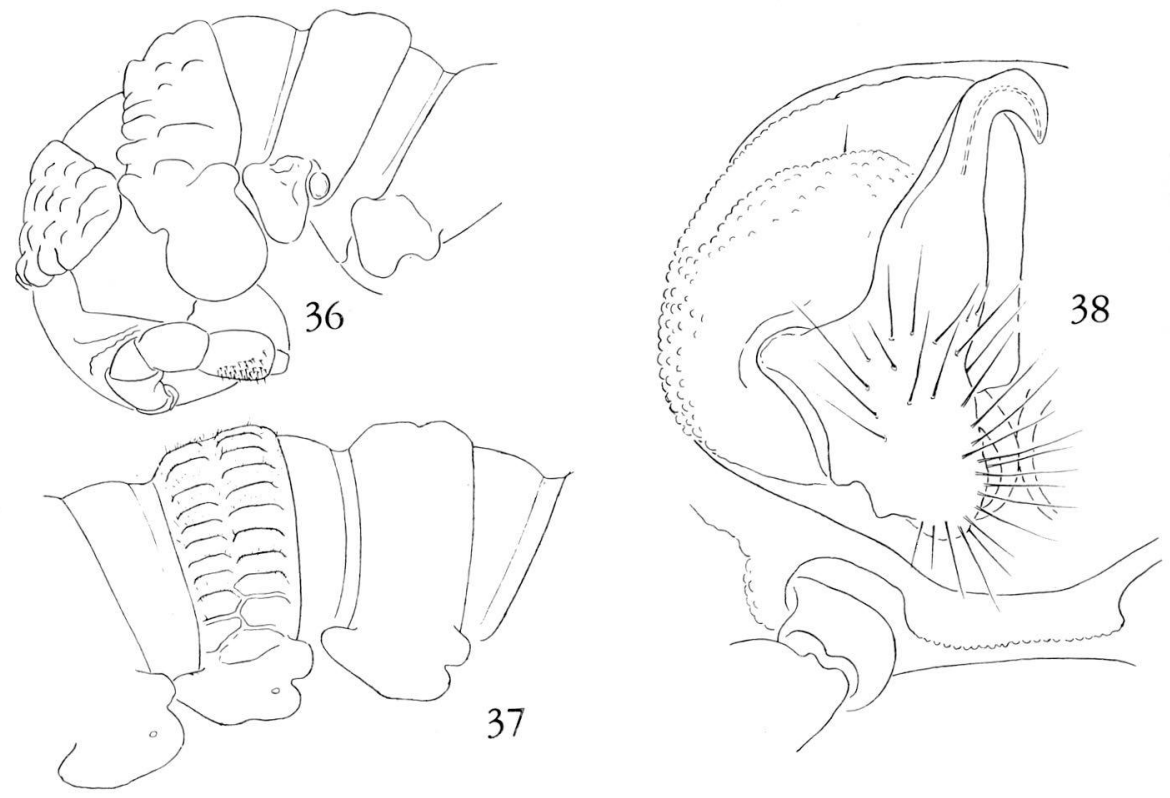
Material. - New Guinea: Papua, Western Province, Finim Tel plateau, cave Selminum Tem. $\hat{o}$ holotype, $2 \hat{\delta}$ and $2 \uparrow$ paratypes, 3 immature specimens, 18 November 1975.

Diagnosis. - With the characters of the genus.

Holotype. - Adult male, length ca. $5.5 \mathrm{~mm}$, width $0.8 \mathrm{~mm}$, body with 18 segments.

Color uniformly pale testaceous, probably white in life. General form of body about as described for $S$. pholeter, but metazona only slightly greater in diameter than prozona, the paranota thus somewhat more widely separated. Metetergal areas only slightly elevated, their surface densely hispidulous, without granulation. Form of collum and anteriormost segments as shown in Figure 36; paranotal lobe of 2 nd segment without the conspicuous raised areas of $S$. pholeter, as shown in Figure 30.

Paranota of the form shown in Figure 37, pores with the same distribution and same location as in $S$. pholeter, but anterior corners much more prominently produced forward, and lobe of the posterior edge more strongly set off and more produced. Anterior half of lateral margin of paranota nearly straight, directed obliquely dorsomediad.

Gonopod structure differing from that of $S$. pholeter in that the prostatic groove does not curve $360^{\circ}$ around the telopodite but remains entirely on the dorsal side entirely to the apex of the short, simple, laminate, apically recurved telopodite (Fig. 38).

Paratype. - Adult $q$, with 18 segments, agreeing closely with male in size and external details of body form.

\section{Family Position Uncertain}

Two specimens of a small polydesmid cannot be referred with confidence to any of the currently recognized families. The species belongs in, or near, the genus Opisthoporodesmus which has been placed in the Polydesmidae by Attems (1940); in my view, however, the form of the gonopod coxa precludes this position and a re-evaluation based on the study of fresh male material is indicated.

\section{?Opisthoporodesmus}

Opisthoporodesmus Silvestri, 1899, Termesz. Fuzetek, vol. 22, p. 206. Type species, $O$. obtectus Silvestri, by monotypy.

\section{Opisthoporodesmus? sp.}

Material. - New Guinea: Papua, Western Province: Finim Tel plateau, Upper Bitip Cave, 1 adult female, 1 immature, 11 November 1975.

Remarks. - Although several species of this genus have been described from New Guinea, most are known only from females. In view of the poverty of the existing descriptions females cannot be distinguished or for that matter 
even referred to Opisthoporodesmus with confidence. Nothing whatever would be gained by the proposal of a formal name for the Bitip Cave species; I do not even necessarily mean to imply that I feel that the generic name here used is correct, and the collection of males is much to be desired.

\section{SUMMARY}

Eight species of polydesmoid millipeds are described from the caves of the extreme northwestern corner of Papua New Guinea. Four new genera are named: in Paradoxosomatidae, Selminosoma, type S. chapmani; Astromontosoma, type $A$. jeekeli; in Doratodesmidae, Scolopopyge, type $S$. pholeter; Selminarchus, type $S$. hispidus. Two additional new species are referred to established genera: Eustrongylosoma exiguum and Nothrosoma beroni, the latter, however, (known only from females) is probably referable to a new genus,

Selminosoma chapmani appears both from its structure and biology to be a true troglobite, the first such species known in the Paradoxosomatidae. The two doratodesmid species extend the known range of this family eastward across Wallace's Line from west Java.

\section{RESUME}

Huit espèces de mille-pattes polydesmoïdes des grottes de l'extrême nord-ouest de la corne de la Nouvelle-Guinée (Papouasie) sont décrites. Quatre nouveaux genres sont nommés: chez les Paradoxosomatidae, Selminosoma, type $S$. chapmani; A stromontosoma, type A. jeekeli; chez les Doratodesmidae, Scolopopyge, type $S$. pholeter; Selminarchus, type $S$. hispidus. Deux nouvelles espèces supplémentaires sont rattachées aux genres déjà établis: Eustrongylosoma exiguum et Nothrosoma beroni, cette dernière cependant (connue seulement à partir de femelles) est probablement à rattacher à un nouveau genre.

Selminosoma chapmani apparaît être un vrai troglobie, à la fois par sa structure et par sa biologie; une telle espèce est la première connue chez les Paradoxosomatidae. Les deux espèces de Doratodesmides étendent vers l'est la zone de répartition connue pour cette famille, depuis l'ouest de Java jusqu'audelà de la Ligne de Wallace.

\section{REFERENCES}

ATTEMS, C., 1914: Die indo-australischen Myriopoden. Arch. Naturg., 80, Abt. A, no. 4: 1-398. 1940. Fam. Polydesmidae, Vanhoeffenidae, Cryptodesmidae, Oniscodesmidae, Sphaerotrichopidae, Peridontodesmidae, Rhachidesmidae, Macellolophidae, in Das Tierreich, Lief, 70: 1-577.

BROOK, D. (ed.), 1976: The British New Guinea Speleological Expedition, 1975. Trans. Brit. Cave Res. Assoc., 3: 113-243< section on speleobiology by P. J. Chapman, pp. 192-203>. 
CHAMberlin, R. V., 1920: The Myriopoda of the Australian Region. Bull. Mus. Comp. Zool., 64: $1-269$.

. 1945: On some diplopods from the Indo-australian Archipelago. Amer. Mus. Nov., no. 1282: $1-43$.

COOK, O. F., 1896a: On recent diplopod names. Brandtia, no. 2: 5-8.

1896b: Cryptodesmus and its allies. Brandtia, no. 5: 19-28.

HOFFMAN, R. L., 1977a: Revalidation of the diplopod family Doratodesmidae and the proposal of a new genus from the Malay Peninsula. Pacific Insects, vol. 17, pp. 247-255.

. 1977b: Diplopoda from Malayan caves, collected by M. Pierre Strinati. Rev. suisse zool., vol. 84 , pp. $699-719$.

JEEKEL, C. A. W., 1955: Milliped miscellany II. Entom. Ber., 15: 412-417.

1967: A revision of the Papuan Paradoxosomatidae (Diplopoda, Polydesmida) in the Museo Civico di Storia Naturale at Genoa. Tijdschr. Ent., 110: 343-379.

1968: On the classification and geographic distribution of the family Paradoxosomatidae (Diplopoda, Polydesmida), pp. 1-162. Amsterdam, privately printed.

. 1973: On the status of the diplopod genus Mimosoma Chamberlin, 1920 (Polydesmida, Paradoxosomatidae). Bull. Zool. Mus. Univ. Amsterdam, 3: 31-37.

POCOCK, R. I., 1894: Chilopoda, Symphyla, and Diplopoda from the Malay Archipelago, in Weber. Zoologische Ergebnisse einer Reise in Niederländisch Ost-Indien, 3: 307-404.

SINCLAIR, F. G., 1901: On the myriapods collected during the "Skeat Expedition" to the Malay Peninsula, 1899-1900. Proc. Zool. Soc. London, 2: 505-533. 